\title{
Effect of Different Levels of Fertilizer and Plant Geometry on Yield Attribute, Grain and Straw Yield of High Zinc Rice Genotypes
}

\author{
Ritu Rani ${ }^{1}$, L. K. Srivastava ${ }^{1}$, G. Chandel $^{2}$ and G. K. Jatav ${ }^{1 *}$ \\ Indira Gandhi Krishi Vishwavidyalaya, Raipur 492012 (CG), India \\ *Corresponding author
}

K e y w o r d s
Zinc, Grain yield,
Straw yield, High
zinc rice genotypes
Article Info
Accepted:
12 March 2020
Available Online:
10 April 2020

\section{A B S T R A C T}

A field experiment was conducted during kharif season of 2015 at Research cum Instructional Farm, Indira Gandhi Krishi Vishwavidyalaya, Raipur (Chhattisgarh). The experiment was laid out with four fertilizers levels viz. F0(00:00:00: N, P and $\left.\mathrm{K} \mathrm{kg} \mathrm{ha}^{-1}\right), \mathrm{F} 1\left(80: 50: 30 \mathrm{~N}, \mathrm{P}\right.$ and $\left.\mathrm{K} \mathrm{kg} \mathrm{ha}^{-1}\right), \mathrm{F} 2\left(110: 60: 40 \mathrm{~N}, \mathrm{P}\right.$ and $\mathrm{K} \mathrm{kg} \mathrm{ha}^{-1}$ ) and $\mathrm{F} 3\left(140: 70: 50 \mathrm{~N}, \mathrm{P}\right.$ and $\left.\mathrm{K} \mathrm{kg} \mathrm{ha}^{-1}\right)$ in main plots and five rice genotypes Viz. RRHZ-7, R-RHZ-MI-30, R-RHZ-LI-22, R-RHZ-HI-11 and R-RHZ-IB-13 in sub plots and two plant geometry $S 1(15 \times 10 \mathrm{~cm}), S 2(20 \times 10 \mathrm{~cm})$ in sub-sub plot in split-split plot design which replicated thrice. Genotype R-RHZ-7 recorded highest number of tillers, panicle and grain while Genotype R-RHZ-MI-30 recorded maximum filled grain and straw yield as compared to other genotype. High fertility levels F3 (140:70:50 N, P and K kg ha ${ }^{-1}$ ) recorded maximum yield attribute and yield as compared to other fertility levels. Closer plant geometry S1 $(15 \mathrm{X} 10 \mathrm{~cm})$ recorded maximum grain and straw yield where wider plant geometry $\mathrm{S} 2(20 \mathrm{X} 10 \mathrm{~cm})$ recorded maximum tiller and panicle.

\section{Introduction}

Rice is the pre-dominant cereal crop in many developing countries and is the staple food for half of the world's population. In Asian countries, rice provides $50-80$ per cent of the energy intake of the poor but it does not provide enough essential micronutrients to eliminate "hidden hunger," in particular iron and zinc deficiency. Micronutrient malnutrition, and particularly $\mathrm{Fe}$ and $\mathrm{Zn}$ deficiency affect over three billion people worldwide, mostly in developing countries (Sperotto et al., 2010).

Zinc deficiency in human body causes undesirable consequences including growth retardation, dermatitis, impaired immune functioning, hypogonadism, delayed wound healing and poor mental development (WHO, 2002). Rice is known as a poor source of essential micronutrients such as $\mathrm{Fe}$ and $\mathrm{Zn}$ 
(Bouis et al., 2010). Fertilizer is one of the key and costliest inputs in realizing the yield potential of high yielding varieties of cereals. Grain yield and nutrient use efficiency of rice genotypes depends upon the level of balance fertilization. Efficient fertilizer use ensures increased production, high profit and environmental protection. For efficient fertilizer use, it is necessary to have the information on optimum doses for a crop under different soil-climate conditions.

Plant spacing has an important role on growth and yield of rice. Optimum plant density ensures the plant to grow properly with their aerial and underground parts by utilizing more solar radiation and soil nutrients (Miah et al., 1990). Closer spacing hampers intercultural operations.

Also in a densely populated crop, the interplant competition is very high for nutrients, air and light, which usually results in mutual shading, lodging and thus favours more straw yield than grain yield. On the other hand, under wider plant spacing desired hill unit ${ }^{-1}$ area cannot be obtained, which ultimately reduces yield unit ${ }^{-1}$ area.

The yield of rice varies with climatic conditions, plant density, fertility level and its interaction with the other yield dependent components (Watson, 1952).

\section{Materials and Methods}

The investigation was conducted on the Research cum Instructional Farm, Indira Gandhi Krishi Vishwavidyalaya, Raipur (Chhattisgarh) during kharif 2015. The experimental consisted of 40 treatments, each replicated three times in split-split plot design. four fertilizers levels viz. F0(00:00:00: N,P and $\left.\mathrm{K} \mathrm{kg} \mathrm{ha}^{-1}\right), \mathrm{F} 1(80: 50: 30 \mathrm{~N}, \mathrm{P}$ and $\mathrm{K} \mathrm{kg} \mathrm{ha}$ $\left.{ }^{1}\right) \mathrm{F} 1\left(80: 50: 30 \quad \mathrm{~N}, \mathrm{P}\right.$ and $\left.\mathrm{K} \quad \mathrm{kg} \mathrm{ha}^{-1}\right)$ F2(110:60:40 N,P and $\mathrm{K} \quad \mathrm{kg} \quad \mathrm{ha}^{-1}$ )
F3(140:70:50 N,P and $\mathrm{K} \mathrm{kg} \mathrm{ha}^{-1}$ ) in main plots and five rice genotypes Viz. R-RHZ-7, R-RHZ-MI-30, R-RHZ-LI-22, R-RHZ-HI-11, R-RHZ-IB-13 in sub plots and two plant geometry $\mathrm{S} 1(15 \mathrm{X} 10 \mathrm{~cm}), \mathrm{S} 2(20 \mathrm{X} 10 \mathrm{~cm})$ in sub-sub plot.

The soil of the experimental field is locally known as Kanhar and identified as Arang II series and it comes under the order of Vertisols. It is clayey in texture, dark brown to black in colour, neutral to alkaline, $5.86 \mathrm{~g}$ $\mathrm{kg}^{-1}$ Organic Carbon, $232 \mathrm{~kg} \mathrm{ha}^{-1}$ available N, $15.2 \mathrm{~kg} \mathrm{ha}^{-1}$ available $\mathrm{P}$ and $460.2 \mathrm{~kg} \mathrm{ha}^{-1}$ available K. Cultural operations were performed as per need.

Grain and straw yield ( $\left.\mathrm{q} \mathrm{ha}{ }^{-1}\right)$ was harvested separately from each net plot of $9 \mathrm{~m}^{2}$. The grains were separated from straw by threshing. The weight of grains was recorded and expressed in $\mathrm{q} \mathrm{ha}^{-1}$ and the straw weight was worked out by subtracting the weight of grains from the bundle weight of the produce and also expressed in $\mathrm{q} \mathrm{ha}^{-1}$.

\section{Results and Discussion}

\section{Number of tiller}

Fertility levels were significantly influenced the number of tillers at 60 days after transplanting of different rice genotypes as shown in the Table 1. Significantly highest tillers of 6.84 hill $^{-1}$ was recorded under high soil fertility level (F3) followed by medium soil fertility level (F2) and low soil fertility levels.

Similar findings were also reported by Salahuddin et al., (2009) Tabar (2012) and Sudhakar et al., (2006). Tillers of rice genotype were also significantly influenced by the plant geometry and different level of fertilizer (Table 1). Tiller of "R-RHZ-7" rice Genotype was found higher number of tillers 
(6.98 tiller hill $^{-1}$ ) as compare to other. Rice genotype grown at $20 \mathrm{~cm} \times 10 \mathrm{~cm}$ apart recorded higher tillers (5.83tiller hill $\left.{ }^{-1}\right)$.

\section{Number of panicle}

The results showed that fertility levels were significantly influenced the number of panicles of different rice genotypes as shown in the Table1. Significantly highest number of panicle $\left(6.13\right.$ hill $\left.^{-1}\right)$ was recorded under high soil fertility level (F3) followed by medium soil fertility level (F2) and low soil fertility levels (F1). Control soil fertility level (F0) recorded significantly lowest number of panicle 3.60 hill $^{-1}$.

Similar result found by Ndaeyo et al., (2008), Metwally et al., (2011) and Sudhakar et al., (2006). The average numbers of panicles were significantly higher in R-RHZ-7(V1) as compared to those of other genotypes in the order of R-RHZ-MI-30 (V2), R-RHZ-IB-13 (V5), R-RHZ-LI-22 (V3). The lowest numbers of panicles $\left(4.31\right.$ hill $\left.^{-1}\right)$ were recorded by R-RHZ-HI-11 (V4). Similar findings were also reported by Sharma et al., (2012). Significantly highest panicle $\left(5.20 \mathrm{hill}^{-1}\right)$ was recorded under wider plant geometry S2 $(20 \times 10 \mathrm{~cm})$ compared closer plant geometry $\mathrm{S} 1(15 \times 10 \mathrm{~cm})$.

\section{Filled grains per panicle}

The results showed that fertility levels were significantly influenced the filled grain panicle $^{-1}$ of different rice genotypes as shown in the Table1. Significantly highest grain panicle $^{-1}$ (81.66 panicle $\left.{ }^{-1}\right)$ was recorded under high soil fertility level (F3) which was at par with medium soil fertility level (F2).

Control (F0) recorded significantly lowest filled grain (60.00 panicle $\left.{ }^{-1}\right)$. Similar findings were also reported by Amin et al., (2004) and Awan et al., (2011). The average number of filled grain panicle ${ }^{-1}$ was found significant higher with R- RHZ-LI-22 (V3) which was at par with R-RHZ-7(V1) but lowest filled grain panicle $^{-1}$ was recorded by R-RHZ-MI-30 (V2) which was at par with R-RHZ-HI-11(V4) and R-RHZ-IB-13(V5). Similar findings were also reported by Salahuddin et al., (2009).

Different plant geometry were not significantly influenced the filled grain panicle $^{-1}$ of different rice genotypes. Highest number of filled grain panicle ${ }^{-1} \quad(74.58$ panicle $^{-1}$ ) was recorded under wider plant geometry S2 (20x10 cm) and Lowest (73.77 panicle $^{-1}$ ) under closer plant geometry S1 $(15 \times 10 \mathrm{~cm})$. Similar findings were also reported by Salahuddin et al., (2009).

\section{Test weight}

The results showed that highest test weight of 18.62 gram was recorded under high soil fertility level (F3) compared to others. Similar results were reported by Salahuddin et al., (2009). The average test weight was significantly higher in R-RHZ-MI-30 (V2) as compared to those of other genotypes in the order of R-RHZ-HI-11(V4), R-RHZ-IB-13 (V5), R-RHZ-LI-22 (V3), R-RHZ-7 (V1).

The lowest test weight of 15.37 gram was recorded by R-RHZ-7 (V1), which was significantly lower than all other genotypes. The variation of test weight was directly correlated with seed size, which is genetic character of different rice genotype. Plant Geometries were not significantly influenced the test weight of different rice genotypes as shown in the Table 1.

Highest Test weight (18.39 gram) was recorded under wider plant geometry S2 $(20 \mathrm{~cm} \times 10 \mathrm{~cm})$ and lowest test weight $(18.25$ gram) was recorded under closer plant geometry $\mathrm{S} 1(15 \mathrm{~cm} \times 10 \mathrm{~cm})$. Similar findings were also reported by Salahuddin et al., (2009). 
Table.1 Effect of different level of fertilizer and plant geometry on yield attributes and yield of high zinc rice genotypes

\begin{tabular}{|c|c|c|c|c|c|c|}
\hline Treatment & $\begin{array}{c}\text { Tiller/ } \\
\text { hill }\end{array}$ & $\begin{array}{c}\text { Panicle/ } \\
\text { hill }\end{array}$ & $\begin{array}{c}\text { Filled } \\
\text { grain/ } \\
\text { panicle }\end{array}$ & $\begin{array}{c}\text { Test } \\
\text { weight }(g)\end{array}$ & $\begin{array}{c}\text { Grain } \\
\operatorname{yield}(q / h a)\end{array}$ & $\begin{array}{c}\text { Straw } \\
\text { yield } \\
\text { (q/ha) }\end{array}$ \\
\hline \multicolumn{7}{|l|}{ Fertilizer } \\
\hline F0(00:00:00) & 4.16 & 3.60 & 60.00 & 18.14 & 16.18 & 20.70 \\
\hline F1(80:50:30) & 5.61 & 5.02 & 75.58 & 18.07 & 38.08 & 44.26 \\
\hline F2(110:60:40) & 6.14 & 5.49 & 79.47 & 18.45 & 43.46 & 50.75 \\
\hline F3(140:70:50) & 6.84 & 6.13 & 81.66 & 18.62 & 44.35 & 50.94 \\
\hline $\mathrm{CD}(\mathrm{P}=\mathbf{0 . 0 5})$ & 0.42 & 0.47 & 5.29 & NS & 2.74 & 3.55 \\
\hline \multicolumn{7}{|l|}{ Genotypes } \\
\hline R-RHZ-7 & 6.98 & 6.19 & 74.84 & 15.37 & 40.03 & 47.37 \\
\hline R-RHZ-MI-30 & 5.73 & 5.12 & 71.75 & 24.03 & 39.67 & 48.92 \\
\hline R-RHZ-LI-22 & 5.30 & 4.74 & 78.23 & 15.97 & 32.29 & 37.97 \\
\hline R-RHZ-HI-11 & 4.87 & 4.31 & 73.83 & 18.97 & 30.97 & 34.21 \\
\hline R-RHZ-IB-13 & 5.56 & 4.94 & 72.20 & 17.28 & 34.62 & 39.85 \\
\hline $\mathrm{CD}(\mathrm{P}=\mathbf{0 . 0 5})$ & 0.47 & 0.27 & 4.15 & 0.42 & 1.43 & 2.11 \\
\hline \multicolumn{7}{|l|}{ Plant geometry } \\
\hline S1 $(15 \times 10 \mathrm{~cm})$ & 5.54 & 4.92 & 73.77 & 18.25 & 37.60 & 44.26 \\
\hline $\mathrm{S} 2(20 \times 10 \mathrm{~cm})$ & 5.83 & 5.20 & 74.58 & 18.39 & 33.44 & 39.06 \\
\hline $\mathrm{CD}(\mathrm{P}=0.05)$ & 0.16 & 0.12 & NS & NS & 0.65 & 0.97 \\
\hline \multicolumn{7}{|l|}{ Interaction } \\
\hline$F^{*} V \quad C D(P=0.05)$ & 0.71 & 0.55 & 3.95 & NS & NS & NS \\
\hline$F^{*} \mathrm{~S} \quad \mathrm{CD}(\mathrm{P}=0.05)$ & NS & NS & 5.01 & NS & NS & NS \\
\hline $\mathrm{V} * \mathrm{~S} \quad \mathrm{CD}(\mathrm{P}=\mathbf{0 . 0 5})$ & NS & NS & NS & NS & NS & NS \\
\hline$F^{*} \mathbf{V} * S \quad C D(P=0.05)$ & NS & NS & NS & NS & NS & NS \\
\hline
\end{tabular}

\section{Grain and straw yield}

The data presented in Table 1 revealed that grain yield were significantly influenced by different fertility levels, rice genotypes and plant geometry. Significantly the highest rice grain and straw yield (44.35 and $\left.50.94 \mathrm{q} \mathrm{ha}^{-1}\right)$ was recorded under high soil fertility level (F3) which was at par with medium soil fertility level (43.46 and 50.75 q ha $\left.{ }^{-1}\right)$, (F2).

Control soil fertility level (F0) recorded the significantly the lowest grain and yield of rice (16.18 and $20.70 \mathrm{q} \mathrm{ha}^{-1}$ ). Similar findings were also reported by Ahmed et al., (2005), Salahuddin et al., (2009) and Sharma et al.,
(2012) Metwally et al., (2011). The average grain yield was significantly higher in $\mathrm{R}$ RHZ-7(V1) as compared to those of other genotypes in the order of R-RHZ-MI-30 (V2), R-RHZ-IB-13 (V5)., R-RHZ-LI-22 (V3).

The lowest grain yield (30.97 $\left.\mathrm{q} \mathrm{ha}^{-1}\right)$ was recorded by R-RHZ-HI-11 (V4). Grain yield was directly dependent on yield components such as number of tillers, test weight, filled grain per panicle. These yield components are genetic character of rice genotype and differ to each other. Similar findings were also reported by Kamara et al., (2010) and Patel et al., (2016). 
The average straw yield was significantly higher in R-RHZ-MI-30 (V2) as compared to those of other genotypes in the order of RRHZ-IB-13 (V5), R-RHZ-LI-22 (V3) but at par with R-RHZ-7(V1). The lowest grain yield (34.21 $\mathrm{q} \mathrm{ha}^{-1}$ ) was recorded by R-RHZHI-11 (V4). Similar findings were also reported by Patel et al., (2016). Significantly highest grain and straw yield (37.60 and 44.26 $\mathrm{q} \mathrm{ha}{ }^{-1}$ ) was recorded under closer plant geometry $\mathrm{S} 1(15 \times 10 \mathrm{~cm})$ and lowest grain yield (33.44 and $39.06 \mathrm{q} \mathrm{ha}^{-1}$ ) under wider plant geometry S2 $(20 \times 10 \mathrm{~cm})$. These results are in consonance with the findings of Venugopal and Singh (1985), Shah et al., (1987), Shrinivasan et al., (1990) and Salahuddin et al., (2009).

On the basis of the results obtained in the present experiment, it may be concluded that highest Number of tillers, panicles, filled grain, grain yield and straw yield were recorded under high soil fertility level (F3) which was at par with medium soil fertility level. The average number of tillers, panicles and grain yields was significantly higher in RRHZ-7(V1) as compared to other genotypes.

Filled grain was found higher in R-RHZ-LI11 rice genotype while test weight and straw yield was higher in R-RHZ-MI-30 (V2) as compared to other genotypes. Significantly highest number of tillers and panicles were recorded under wider plant geometry S2 $(20 \times 10 \mathrm{~cm})$ and highest grain yield $(37.60$ $\mathrm{qha}^{-1}$ ) and straw yield (44.26 $\mathrm{q} \mathrm{ha}^{-1}$ ) was recorded under closer plant geometry $\mathrm{S} 1$ $(15 \times 10 \mathrm{~cm})$.

\section{References}

Ahmed, M., Islam, M.M., and Paul, S.K. (2005) Effect of Nitrogen on Yield and Other Plant Characters of Local $T$. Aman Rice, Var. Jatai. Research Journal of Agriculture and Biological
Sciences 1(2): 158-161.

Amin, M., Ayyaz, M., Ahmed and Ramzan, M. (2004) Effect of increased plant density and fertilizer dose on the yield of rice variety IR-6. Journal of Research (Science) 15(1): 09-16.

Awan, T.H., Ali, R.I., Manzoor, Z., Ahmad, M. and Akhtar, M. (2011) Effect of different nitrogen levels and row spacing on the performance of newly evolved medium grain rice variety, ksk133. The Journal of Animal \& Plant Sciences 21(2): 231-234.

Bouis, H.E. and R.M. Welch. 2010. Biofortification a sustainable agricultural strategy for reducing micronutrient malnutrition in the global south. Crop Science 50:20-32.

Kamara, A.Y., Ekeleme, F., Omoigui, L.O., and Chikoye, D. (2011) Influence of nitrogen fertilization on yield and yield components of rain-fed lowland NERICA rice in the northern Guinea savanna of Nigeria. African Journal of Agricultural Research 6(13): 30923097.

Metwally, T.F., Gewaily, E. E., and Naeem, S.S. (2011) Nitrogen response curve and nitrogen use efficiency of Egyptian hybrid rice. Journal of Agricultural Research. Kafer El-Sheikh University, 37(1): 73-84

Miah, M.H.N., Rehman, M.M., and Islam, M.S. (1990) Performance of nizersail mutants under different row spacing. Bangladesh Journal of Training and Development. 3(2):31-34.

Ndaeyo, N.U., Iboko, K.U. and Edem, S.O. (2008) Growth and yield performances of some upland rice cultivars as influenced by varied rates of NPK fertilizer on an Ultisol. Journal of Tropical Agriculture, Food, Environment and Extension, 7 (3): 249255.

Patel, T., Nayak, T., and Mishra, V. N. (2016) 
Effect of different fertility levels and nutrient uptake by drought tolerant rice genotype under rainfed condition. The Bioscan. 11(1):401-406.

Salahuddin, K. M., Chowhdury, S. H., Munira, S., Islam, M. M., and Parvin, S. (2009) Response of nitrogen and plant spacing of transplanted aman rice. Bangladesh J. Agril. Res. 34(2): 279285

Shah, M. H., Khusu, M. K. and Bali, A. S. (1987) Effect of spacing and number of seedlings per hill on transplanted rice. Oryza, 24 (1): 67-69.

Sharma, Dinesh., Sagwal, P. K., Singh, I,. and Sangwan, A. (2012) Influence of Different Nitrogen and Phosphorus Levels on Profitability, Plant Nutrient Content, Yield and Quality in Basmati Cultivars. International Journal of IT, Engineering and Applied Sciences Research. 1(1):1-4.
Sperotto, R. A., T. Boffa, G. L., Duartea, L. S., Santosb, M. A., Grusakc and J. P. Fett (2010) Identification of putative target genes to manipulate $\mathrm{Fe}$ and $\mathrm{Zn}$ concentrations inrice grains. Journal of Plant Physiology. 167:1500-1506

Srinivasan, K. 1990. Effect of plant spacing on ratoon rice performance. IRRN, 15 (4): 21.

Tabar, Y. 2012. Effect of nitrogen and phosphorus fertilizer on growth and yield rice (Oryza sativa L). International Journal of Agronomy and Plant Production 3(12): 579-584

Venugopal, K. and Singh, R.D. (1985) Effect of plant density and age of seedling on the yield of DR-92 rice in Sikkim. Oryza, 22(2): 162-165.

Watson, D.J. (1952) The physiological basis of variation in yield. Advance in Agronomy 4:141-145.

WHO (2002): The World Health Report. 55

\section{How to cite this article:}

Ritu Rani, L. K. Srivastava, G. Chandel and Jatav, G. K. 2020. Effect of Different Levels of Fertilizer and Plant Geometry on Yield Attribute, Grain and Straw Yield of High Zinc Rice Genotypes. Int.J.Curr.Microbiol.App.Sci. 9(04): 1677-1682. doi: https://doi.org/10.20546/ijcmas.2020.904.196 